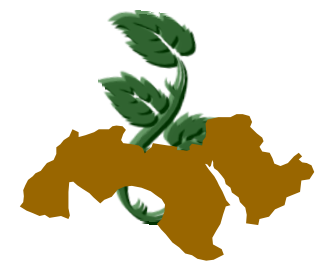

Arab Univ. J. Agric. Sci., Ain Shams Univ., Cairo, 23(1), 25 - 36, 2015

\title{
EFFECT OF USING SOME TREATMENTS ON SWEET PEPPER IRRIGATION AND ITS EFFECT ON FRUIT YIELD AND ITS QUALITY
}

\author{
Usrya, A.I. Byan ${ }^{1}$ and Nahed, M.M. El-Shimi ${ }^{1}$ \\ 1- Veg. Res. Dep., Hort. Res. Inst., Agric. Res. Center, Giza, Egypt
}

Keywords: Sweet pepper, Irrigation intervals, Super absorbent polymer (SAP), Compost

\begin{abstract}
Two field experiments were carried out during two summer seasons of 2013 and 2014 years at the Experimental Farm of Kaha Station, Qalubia Governorate to study the effect of using three irrigation intervals $(7,15$ or 21 day) and five treatments of water absorbent substrates as adding to soil before transplanting ,i.e. (without substrates (control), SAP at $15 \mathrm{~kg} / \mathrm{fed}$., SAP at $20 \mathrm{~kg} / \mathrm{fed}$., compost at $5 \mathrm{t} / \mathrm{fed}$. and compost at $10 \mathrm{t} / \mathrm{fed}$.) on sweet pepper plants c.v. Mohanad and the effect of that on growth, yield, physical and chemical characters of sweet pepper fruits. The results indicated that, the highest values of all vegetative growth parameters, yield and yield components were registered by the treatment of 7 days or 15 day irrigation intervals. Concerning of using water absorbent substrates, it was found that, pepper plants grown in the soil fertilized at $10 \mathrm{t} / \mathrm{fed}$. or treated with super absorbent polymer (SAP) 20 $\mathrm{kg} / \mathrm{fed}$., respectively gave the highest values of vegetative growth parameters, yield and yield components. It is obvious that the plants fertilized at $10 \mathrm{t} / \mathrm{fed}$. and irrigated every 7 days gave the highest values of fruit length, fruit diameter, fresh fruit weight and total yield. While, plants treated with SAP at $20 \mathrm{~kg} / \mathrm{fed}$. and irrigated every 15 day gave the highest values of fruit diameter and fresh fruit weight, but the differences did not reach to significance level for fruit length and early yield in both growing seasons. On the other hand, compost at $10 \mathrm{t} / \mathrm{fed}$., compost at $5 \mathrm{t} / \mathrm{fed}$. and SAP at 20 $\mathrm{kg} / \mathrm{fed}$. with irrigation every 21 day were the best
\end{abstract}

(Received 15 December, 2014)

(Accepted 13 January, 2015) treatments for yield and yield components of pepper plants.

Generally, it can recommend by using compost at $5 \mathrm{t} /$ fed., or super absorbent polymer (SAP) at 20 $\mathrm{kg} / \mathrm{fed}$. with irrigation every 15 days and this mean that increased the irrigation period without any injury or statistical effect on the fruit crop to obtain high pepper fruit yield with height quality and height net income to the growers.

\section{INTRODUCTION}

Pepper (Capsicum annuum L.) plants are sensitive to water stress during the establishment period and fruit setting, (Doorenbos and Kassam, 1986). High levels of irrigation are often applied in order to maximize yields. However, field observations suggest that excessive irrigations may negatively affect pepper plants.

Egypt is a country with tremendous land resources but limited water resources. The cultivated area is only $3.3 \%$ of geographical area. The main water source for Egypt is Nile River and few amounts from underground water. The total water resources in Egypt are 55.5 billion $\mathrm{m}^{3}$ from Nile River, in addition to 6 billion $\mathrm{m}^{3}$ from groundwater. The agricultural sector consumes $84 \%$ of the water resources. It would be much difficult to meet the food requirements in the future with the declining water resources and limited clean water reservoirs in the future, as $70 \% \sim 90 \%$ of the available water resources is used in food production.

Jaimez et al (2000), Costa and Gianquinto (2002) and Antony and Singandhupe (2004) reported that continuous water stress significantly reduced total fresh weight of fruit and total pepper yield. Irrigation should begin before the crop comes under severe water stress by enough peri- 
ods to reduce water stress injury on crop yield or quality. The level of stress that will cause a reduction in crop yield or quality depends on the kind of crop and its stage of development as well as the water condition during the growing season (Okesusi and Olorunwa, 2006). Moreover, adequate amount of water is needed at the right time in order to get higher crop yield and should be applied to farmlands. Therefore, it is vital to determine the water consumptions of plants and periods that plants are susceptible for water beside the irrigation intervals in order to increase crop yield, (Ngouajio et al 2008). In this regard, Khan et al (2009) on pepper showed that, when six water treatments i.e. watering once every day $\left(\mathrm{W}_{1}\right)$, watering twice everyday $\left(\mathrm{W}_{2}\right)$, watering at 4 days interval $\left(\mathrm{W}_{3}\right)$, watering at 8 days interval $\left(\mathrm{W}_{4}\right)$, watering at 16 days interval $\left(\mathrm{W}_{5}\right)$, and no watering $\left(\mathrm{W}_{0}\right)$ were tested. The results revealed that, plant height, no. of leaves per plant, leaf area per plant, canopy diameter, leaf dry weight, stem dry weight, no. of fruits per plant, fruit length, fruit diameter, individual fruit weight, fruit yield per plant, fruit dry weight per plant, showed lowest values of these parameters by either deficit or excess water treatments. By increasing irrigation interval, stem diameter, plant height, leaf area, fresh weight and dry weight of root and shoot were reduced. Moreover, the larger irrigation interval resulted in lower yields and quality of pepper such as number of fruit, mean fruit weight, pepper length and width (Sezen et al 2011, Sayyari et al 2012 and Abayomi et al 2012). Also, Adeoye et al (2014) showed that the irrigation intervals used (daily, 3 days, six days and 9 days and a no-irrigation) shows significant influence of irrigation intervals on pepper yield and some growth parameters. The irrigation interval also has remarkable influence on stem diameter but with little effect on stem height and leaf number.

Concerning vitamin C, Mitchell et al (1991), Liu and Chen (2002) and Mahajan and Singh (2006), reported that vitamin C concentration in tomato fruits increased with lower water supply.

One of the most important factors of costs in production and maintenance of plants is irrigation. It was found that, one method of water conservation and reduction of irrigation costs is using super absorbent polymer (SAP) as soil improvement substances. SAPs are hydrogels that can absorb considerable amount of water, saltwater or physiological solutions. These polymers besides having high speed and capacity of water absorption also act as miniature water storage place and give water easily, if required. Using SAP in the production of tomato increased the yield by $35 \%$ and facilitated the fruits ripening and nutrient elements are increased and losses or washing amount of the elements is reduced as mentioned by, (Bjorneberg et al (2003); Flanagan et al 2003 and ElHadi and Camelia, 2004). These substances absorb about 200 to 500 times as much water as their weight and after 5 to 12 years are gradually destroyed because of microbial disintegration or sun ray effect and are changed into some substances as water, carbon dioxide and ammonium (Poresmaiil et al 2007). Yazdani et al (2007) reported that using absorbent polymer under drought stress and water shortage conditions can increase the yield of soybean. Positive effects of polymer on crop yields and growth activities can be found in the researchers of Abu-Zreig et al (2007) and Lentz and Sojka (2009).

Sayyari and Ghanbari (2012) indicated that, by increasing irrigation intervals $(5,7,9,11$ days) under drought stress, pepper growth parameters, yield and chlorophyll were reduced. In this study, super absorbent polymer application A200 (0, 0.2, $0.3,0.4,0.5$ weight percent) reduced prolonged irrigation effects on pepper by increasing growth rate, yield, leaf chlorophyll. The results of this study showed also that SAP can store and absorb considerable water and reduce negative effects of water shortage on plants.

The use of compost has been used to increase crop productivity and yields, and their use is usually associated with improved soil structure and enhanced soil fertility, increased soil microbial populations, significantly increased tomato plant dry biomass, fruit diameter, yield and water use efficiency (WUE) and an improved moisture-holding capacity of the soil (Arancon, et al 2004; Ali, 2005; Curtis and Claassen, 2005; Lakhdar et al 2009 and Tejada et al 2009). Moreover, Nguyen et al (2012) reported that, addition compost to tomato or pepper plants increased shoot and root growth as well as fruit yield.

Thus, based on positive properties of SAP or compost, the objective of this study was to evaluate the effects of applying SAP or compost on pepper plant under different irrigation periods. Our specific objectives were: (1) The determination of the best amount of SAP or compost application in soil, and (2) Determining the best irrigation interval for pepper with or without super absorbent substrates.

MATERIALS AND METHODS 
The experiment was conducted at the Experimental Farm of Kaha Station, Qalubia Governorate; in the clay soil. The present investigation was conducted during tow successive seasons of 2013 and 2014. Seeds of sweet pepper (Capsicum annum L. Cv. Mohanad) were sown under plastic house in nursery at first week of February during both 2013 and 2014 seasons and received natural agricultural practices. After 50 day from sowing healthy seedlings were selected and transplanted on the field plot $(35 \mathrm{~cm}$ apart). The plot area was $\left(8.4 \mathrm{~m}^{2}\right)$ and includes 3 ridges each of $(0.7 \mathrm{~m})$ width and $(4.0 \mathrm{~m})$ length. A split plot design system with three replicates was adopted. Fifteen treatments, i.e., the combination among three irrigation intervals ( 7 days, 15 day and 21 day) were distributed in the main plots .In addition, tow super absorbent substances with tow concentration (SAP at $15 \mathrm{~kg} / \mathrm{fed}$., SAP at $20 \mathrm{~kg} / \mathrm{fed}$., compost at $5 \mathrm{t} / \mathrm{fed}$., compost at $10 \mathrm{t} / \mathrm{fed}$. and control without any addition) which was arranged in the sub plots. SAP and compost were added to soil before sowing during soil preparation at $15 \mathrm{~cm}$ depth.

Table 1. Names and contains of the materials used in this study

\begin{tabular}{|l|l|}
\hline Substrate name & \multicolumn{1}{|c|}{ Composition } \\
\hline SAP & \multicolumn{1}{|c|}{ Polyacrylamide } \\
\hline Compost & Moisture 27.5\%, PH 7.4, EC \\
& $3.8(\mathrm{ds} / \mathrm{m})$, Total nitrogen 1.6\%, \\
& Organic matter 45\%, Organic \\
& carbon 25\%, C/N ratio 01:15, \\
& Total phosphor 0.6\%, Total \\
& potassium 1.3\% and Calcium \\
& $0.7 \%$. \\
\hline
\end{tabular}

The other agricultural practices were followed according to the recommendation for sweet pepper plantation. The following data were recorded as follows:

\section{Vegetative growth parameters}

Three plants were chosen randomly from each treatment in the three replicates at the beginning of flowering stage in order to determine the following: - Plant length (the length of main stem $\mathrm{cm}$ ) -Leaves number/plant.

-Fresh weight and dry weight ( $\mathrm{g} / \mathrm{plant})$ : A random sample of other three plants from each plot was taken and dried at $70 \mathrm{C}$ - till constant weight and the dry weight of whole plant was determined using the standard methods as illustrated by A.O.A.C (1990).

- No. of. brunches/ plant .

The leaf area was calculated according to the following formula of Wallace and Munger (1965): Leaf area $\left(\mathrm{cm}^{2}\right)=$ Leaves dry weight $(\mathrm{gm}) \times$ disk area / Disk dry weight (gm)

Total leaf chlorophyll content was measured using Minolta chlorophyll meter SPAD- 501 as SPAD units

\section{2- Fruit yield and its characteristics}

Five sweet pepper fruits were randomly selected from each plot to determine the following data:

Fruit length $(\mathrm{cm})$ - Fruit diameter $(\mathrm{cm})$ - Average fruit weight $(\mathrm{g})$ - Dry fruit weight $(\mathrm{g}): 100 \mathrm{~g}$ from fruits was taken and dried at $70 \mathrm{C}$ - till constant weight and the dry weight was determined - Early fruit yield(ton/fed) as the first and second pickingsTotal fruit yield (ton/fed)-

Total ascorbic acid: (Vitamin C mg/100g fresh weight) content was determined by using the die 2 , 6 dichlorophenol indophenols, method as described by Ranganna(1979).

\section{3- Soil moisture percentage}

Before 2 day of irrigation interval, the sample of soil was collected in soil core and oven dried at 105 Co (for 24 hours) or till constant weight and the dry weight of the soil was determined. The moisture contents of the samples were determined using the standard methods as illustrated by A.O.A.C, (1990).

\section{4- Economic study}

A study of economic gain for different water absorbed substrates treatments were estimated by subtract the price of total fruit yield and cost of substrates treatments to obtained income in Egyptian pounds.

\section{5-Statistical analysis}

Data obtained were subjected to the proper analysis of variance (split-plot design) as described by Snedecor and Cochran (1980) using M. stat program. Averages between treatments were differentiated by using LSD at $5 \%$ level.

\section{RESULTS AND DISCUSSION}


1- Effect of irrigation intervals, water absorbent substrates and interaction on vegetative growth and leaf chlorophyll concentration

\subsection{Effect of irrigation intervals}

Data in Table (2) show that statistical analysis $(p<0.05)$ revealed that the change in irrigation interval has a significant effect on the vegetative growth parameters of sweet pepper plants, i.e., plant length, number of leaves/plant, leaf area, number of brunches/ plant as well as the fresh and dry weight of plant, the highest values of all vegetative growth parameters were obtained in the plot with 7 days or 15 day irrigation intervals. These results are in the same line with those obtained by (Khan et al 2009; Sezen et al 2011; Sayyari et al 2012 and Abayomi et al 2012) on sweet pepper. On the other hand, leaf chlorophyll contents, data in Table (2) revealed that plants were irrigated every 21day showed the lowest concentration of chlorophyll in the leaves than those irrigated every 7 or 15 day. The results are true in both growing seasons in this regard (El-Hadi and Camelia, 2004). Sayyari and Ghanbari (2012) indicated that, by increasing irrigation intervals $(5,7,9,11$ days) under drought stress, sweet pepper chlorophyll was reduced.

\subsection{Effect of water absorbent substrates}

As shown in Table (2), sweet pepper plants grown in the soil fertilized with compost at $10 \mathrm{t} / \mathrm{fed}$ or super absorbent polymer (SAP) at $20 \mathrm{~kg} / \mathrm{fed}$, respectively gave the highest values of vegetative growth parameters, i.e., number of leave/plant, leaf area, number of brunches/ plant as well as the fresh and dry weight of plant in both growing season and plant length in the second season. The results of this study may be due to that SAP can store and absorb considerable water and reduce negative effects of water shortage on sweet pepper plants. Positive effects of polymer on growth activities were reported by Bjorneberg et al (2003); Flanagan et al (2003); Abu-Zreig et al (2007); Lentz and Sojka (2009) and Sayyari and Ghanbari (2012). Moreover, Ali, (2005) and Nguyen et al (2012) showed that, compost addition to tomato or pepper plants increased shoot and root growth. While, concerning to leaf chlorophyll contents, data in Table (2) revealed that adding compost at $5 \mathrm{t} / \mathrm{fed}$. or $10 \mathrm{t} / \mathrm{fed}$ showed the highest concentration of chlorophyll in the leaves. The use of compost is usually associated with improved soil structure and enhanced soil and plant fertility, (Arancon, et al 2004).

\subsection{Effect of the interaction between irrigation intervals and water absorbent substrates}

The results of the interaction effect between irrigation intervals and water absorbent substrates on vegetative growth, i.e., plant length, number of leaves, leaf area, number of brunches/ plant and fresh as well as dry weight of sweet pepper plant are shown in Table (2). It is obvious that plants fertilized with compost at $10 \mathrm{t} / \mathrm{fed}$ or adding SAP $20 \mathrm{~kg} / \mathrm{fed}$, respectively and irrigated every 7 days gave the highest values of number of leaves/plant, as well as fresh and dry weight. On the other hand, SAP at $20 \mathrm{~kg} / \mathrm{fed}$ or compost at $5 \mathrm{t} / \mathrm{fed}$, respectively and irrigated every 15 days gave the highest values of plant length, data revealed also that compost at $10 \mathrm{t} / \mathrm{fed}$ or compost at $5 \mathrm{t} / \mathrm{fed}$, respectively and irrigation interval 7 days were the best treatments for leaf area. Concerning number of brunches/ plant, the data did not exert any significant effect in both growing season. SAP is hydrogels that can absorb considerable amount of water. These polymers besides having high speed and capacity of water absorption also act as miniature water storage place and give water easily. This substance, i.e. SAP absorbs about 200 to 500 times as much water as their weight and reduces negative effects of water drought (Poresmaiil et al 2007). The use of compost has been used to increase crop productivity and their use is usually associated with improved soil structure and enhanced soil fertility, and an improved moistureholding capacity of the soil (Lakhdar et al 2009 and Tejada et al 2009). Data revealed also that compost at $5 \mathrm{t} / \mathrm{fed}$. or compost at $10 \mathrm{t} / \mathrm{fed}$, respectively and irrigation interval 21 day were the best treatments for total leaf chlorophyll in both growing season.

2- Effect of irrigation intervals, water absorbent substrates and interaction on yield and its fruits quality

\subsection{Effect of irrigation intervals}

The yield and yield components of sweet pepper plants, i.e. fruit length, fruit diameter, fresh fruit weight, dry fruit weight, early and total yield as affected by irrigation intervals are shown in Table (3). The data reveal that the highest values of fruit length, fruit diameter, fresh fruit weight, total and early yield were registered in the plot with 7 days 
or 15 days irrigation intervals, respectively in both growing seasons. Although the differences did not reach to significance level for fruit diameter. In this regard (Sezen et al 2011; Sayyari et al 2012 and Abayomi et al 2012) came to similar result. Also, Adeoye et al (2014) indicated that, the larger irrigation interval resulted in lower yields and quality of sweet pepper such as number of fruit, mean fruit weight, fruit length and width.

Concerning dry fruit weight irrigation interval 21 days gave the highest means. Moreover, it was found that the plants irrigated every 21 days produced fruits containing the highest values of vitamin. C compared with those supplied every 7 or 15 days, the results are true in both growing seasons. This result may be due to applying lower water treatment caused osmotic adjustment in the pericarp of pepper fruit and resulted in higher ascorbic acid content (Mitchell et al 1991). The results herein are in the same line of the results obtained by, Liu and Chen (2002); Mahajan and Singh (2006), they reported that vitamin C concentration in tomato fruits increased with lower water supply.

\subsection{Effect of water absorbent substrates}

Yield and yield attributes of sweet pepper showed significant results by using different water absorbent substrates as shown in Table (3). The data showed that the plants treated with polymer (SAP) at $20 \mathrm{~kg} / \mathrm{fed}$ or compost at $10 \mathrm{t} / \mathrm{fed}$ gave the highest values of fruit length, fruit diameter, fresh and dry fruit weight, V.C, early and total yield. These results are agreements with those obtained by Bjorneberg et al (2003); Flanagan et al (2003); Abu-Zreig et al (2007); Lentz and Sojka (2009) and Sayyari and Ghanbari (2012) on sweet pepper. Moreover, Yazdani et al (2007) reported that using absorbent polymer under drought stress condition and water shortage conditions can increase the yield of soybean. Using SAP in the production of tomato increased the yield by $35 \%$. The additions of rice straw compost, significantly increased tomato plant dry biomass, fruit diameter, yield, Ali, (2005). Moreover, Nguyen et al (2012) reported that, compost addition to tomato or pepper plants increased fruit yield.

\subsection{Effect of the interaction between irrigation intervals and water absorbent substrates}

The results of the interaction effect between irrigation intervals and water absorbent substrates on yield and yield components of sweet pepper plants are shown in Table (3), it is obvious that the plants grown in soil fertilized with compost at $10 \mathrm{t}$ /fed and irrigated every 7 days gave the highest values of fruit length, fruit diameter, fresh fruit weight, total yield. While, plants treated with SAP at $20 \mathrm{~kg} / \mathrm{fed}$. and irrigated every 15 days gave the highest values of fruit diameter and fresh fruit weight but the differences did not reach to significance level for fruit length and early yield in both growing seasons, but in the same irrigation interval compost at $10 \mathrm{t} / \mathrm{fed}$ was the best for dry fruit weight and total yield. On the other hand, compost at 10 $\mathrm{t} / \mathrm{fed}$., compost at $5 \mathrm{t} / \mathrm{fed}$. and SAP at $20 \mathrm{~kg} / \mathrm{fed}$. with irrigation every 21 days were the best treatments for yield and yield components of sweet pepper plants. Positive effects of polymer on crop yields were illustrated by Bjorneberg et al (2003); (Flanagan et al 2003); Abu-Zreig et al (2007) and Lentz and Sojka (2009). Concerning to V.C it is obvious that irrigation every 21 days without adding any substrate gave the highest values of it, this result may be due to the lowest sweet pepper fruit yield under drought stress, hence enhanced the accumulation and the concentration of ascorbic acid in the remaining fewer fruits.

3- Effect of irrigation intervals, water absorbent substrates and interaction on soil moisture percentage

\subsection{Effect of irrigation intervals}

The effect of irrigation intervals are shown in Fig. (1). The data reveal that the highest values of soil moisture percentage were obtained from the soil was irrigated every 7 days followed by 15 days in both growing season.

\subsection{Effect of water absorbent substrates}

As shown in Fig. (2), the soil treated with super absorbent polymer (SAP) at $20 \mathrm{~kg} / \mathrm{fed}$. or compost $10 \mathrm{t} / \mathrm{fed}$., respectively gave the highest values of soil moisture percentage in both growing season although the differences did not reach to significant level in the first season. These result may be due to that super absorbent polymer absorb about 200 to 500 times as much water as their weight, besides having high speed and capacity of water absorption also act as miniature water storage place and give water easily under requirement condition (Poresmaiil et al 2007). Moreover, using compost improves moisture-holding capacity of the soil (Lakhdar et al 2009 and Tejada et al 2009). 


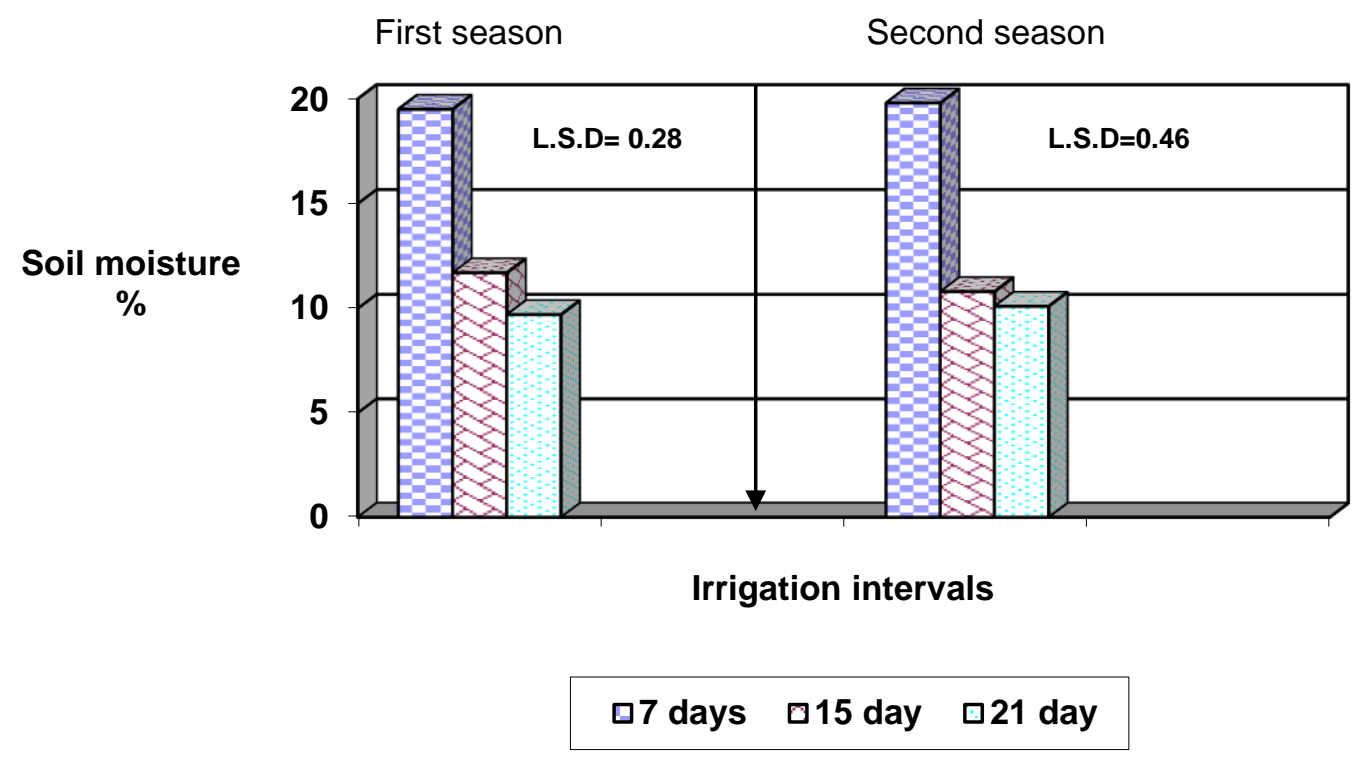

Fig. 1. Effect of irrigation intervals on soil moisture percentage of sweet pepper plants during the two seasons of 2013 and 2014

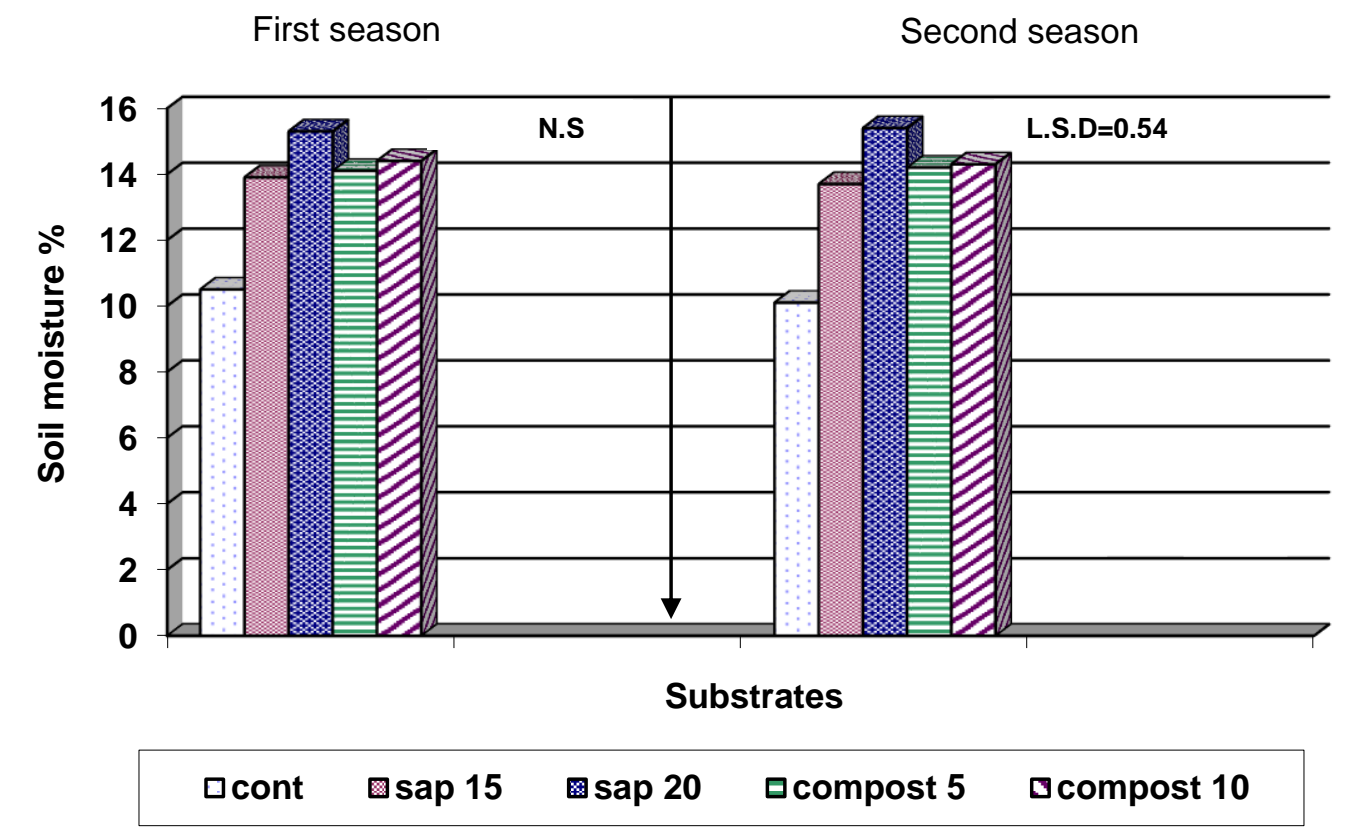

Fig. 2. Effect of water absorbent substrates on soil moisture percentage of sweet pepper plants during the two seasons of 2013 and 2014 


\subsection{Effect of the interaction between irrigation intervals and water absorbent substrates}

The results of the interaction effect between irrigation intervals and water absorbent substrates on soil moisture percentage are shown in Fig. (3). It is obvious that soil fertilized with compost at 10 $\mathrm{t} / \mathrm{fed}$. or compost at $5 \mathrm{t} / \mathrm{fed}$., respectively and irrigated every 7 days gave the highest values of soil moisture percentage. On the other hand, SAP at 20 or $15 \mathrm{~kg} / \mathrm{fed}$, respectively and irrigated every 15 day were the best treatments, data revealed also that, in the case of irrigation every 21 days the highest percentage of soil moisture noticed under using SAP at $20 \mathrm{~kg} / \mathrm{fed}$ followed by compost treatments in both growing season although the differences did not reach to significant level in the first season. This results may be due to that compost improved moisture-holding capacity of the soil (Ali, 2005; Curtis and Claassen, 2005; Lakhdar et al
2009 and Tejada et al 2009). It can said that, using SAP substrate showed highest moisture, holding capacity and increased the period of irrigation from 7 to 15 days without any injury in soil water content.

\section{Economic study}

Data in Table (4) show the total income per feddan under different quantity from SAP or compost treatments. It is evident from such data that adding compost at $5 \mathrm{t} / \mathrm{fed}$., compost at $10 \mathrm{t} / \mathrm{fed}$., SAP at $20 \mathrm{~kg} / \mathrm{fed}$. or SAP at $15 \mathrm{~kg} / \mathrm{fed}$., respectively gave higher total income/feddan than control treatment.

Generally, it can say that, adding compost at 5 $\mathrm{t} / \mathrm{fed}$., then SAP at $20 \mathrm{~kg} / \mathrm{fed}$. with irrigation every 15 days gave the highest sweet pepper fruit yield with height quality and height net income to the growers.

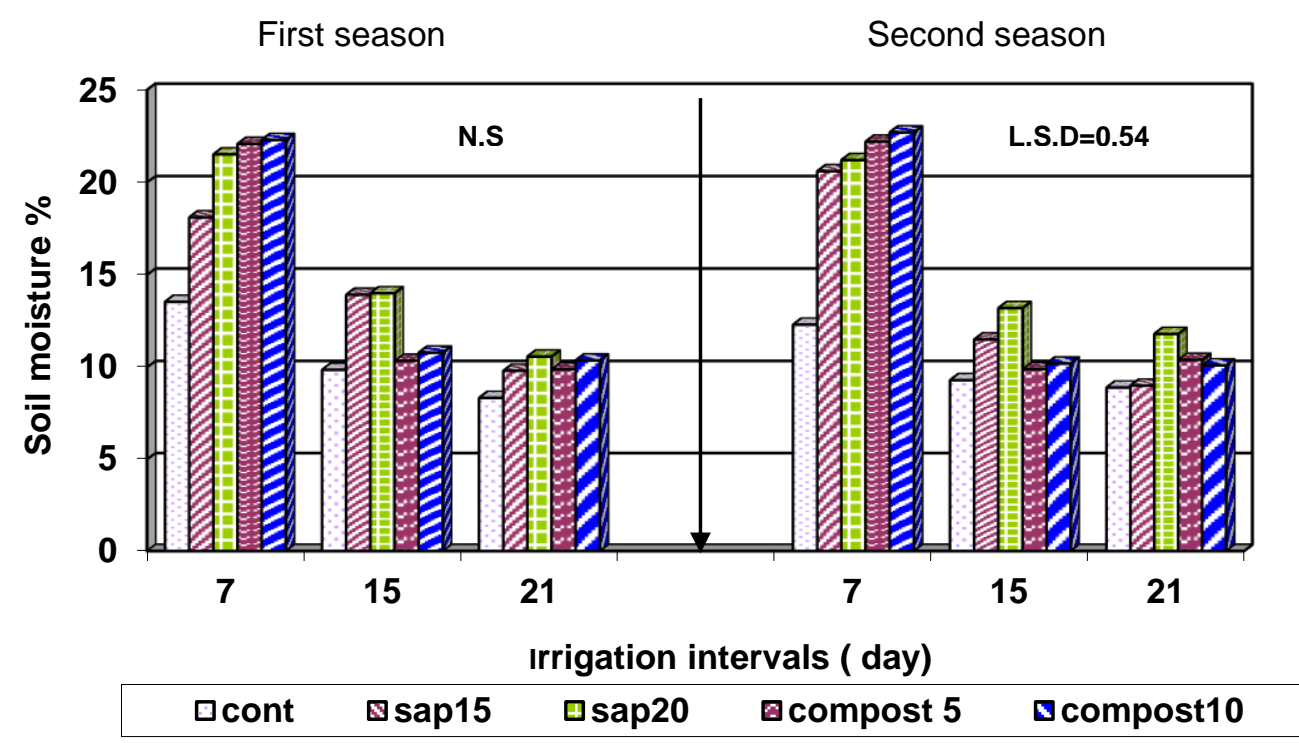

Fig. 3. Effect of interaction between irrigation intervals and water absorbent substrates on soil moisture percentage of sweet pepper plants during the two seasons of 2013 and 2014.

Table 4. Effect of water absorbent substrates on net income/feddan of sweet pepper plants during the average of two seasons of 2013 and 2014

\begin{tabular}{|c|c|c|c|c|}
\hline Treatments & $\begin{array}{c}\text { Average } \\
\text { total yield } \\
\text { (ton/fed.) }\end{array}$ & $\begin{array}{c}\text { Total income } \\
\text { Egyptian pound } \\
\text { before adding the } \\
\text { cost of substrates }\end{array}$ & $\begin{array}{c}\text { Cost of adding } \\
\text { the substrates to } \\
\text { one feddan } \\
\text { (E.P) }\end{array}$ & $\begin{array}{c}\text { Total income after } \\
\text { adding the substrates } \\
\text { without cost of } \\
\text { agriculture practices }\end{array}$ \\
\hline Without (cont) & 2.59 & 7770 & 0000 & 7770 \\
SAP 15kg/fed & 4.42 & 13260 & 2100 & 11160 \\
SAP 20kg/fed & 5.16 & 15480 & 2800 & 12680 \\
Compost 5t/fed & 4.89 & 14670 & 1750 & 12920 \\
Compost 10t/fed & 5.41 & 16230 & 3500 & 12730 \\
\hline
\end{tabular}

${ }^{*}$ Price of sell one ton of sweet pepper fruits during the season $=3000 \mathrm{~L}$.E.

* Price of sell one kg of SAP $=140$ L.E. * Price of sell one ton of compost $=350$ L.E. 


\section{REFERANCES}

Abayomi, Y.A., Aduloju, M.O., Egbewunmi, M.A. and Suleiman, B.O. 2012. Effects of soil moisture contents and rates of NPK fertilizer application on growth and fruit yields of pepper (Capsicum sp.) genotypes. International. J. Agri. Sci., 2(7): 651-663.

Abu-Zreig, M., Al-Sharif, M. and Amayreh, J. 2007. Erosion control of arid land in Jordan with two anionic polyacrylamides. Arid Land Res Manag 21: 315-328.

Adeoye, P.A., Adesiji, R.A., Oloruntade, A.J. and Njemanze, C.F. 2014. Effect of irrigation intervals on growth and yield of Bell Pepper (Capsicum annuum) in a tropical semi-arid region. Amer. J. of Experimental Agric. 4(5): 515-524.

Ali, H.I. 2005. Effect of Rice Straw Compost and Water Regimes on Growth Performance of Tomato (Lycopersicun Esculentum L.). Ph.D thesis, Universiti Putra Malaysia. pp.140145.

Antony, E. and Singandhupe, R.B. 2004. Impact of drip and surface irrigation on growth, yield and WUE of capsicum (Capsicum annuum L.). Agric. Water Manage. 65(2): 121-132.

A.O.A.C. 1990. Official Methods of Analysis of Association of Official Agricultural Chemists. 15th: 1045-1106.

Arancon, N.Q., Edward, C.A., Atiyeh, R.M. and Metzger, J.D. 2004. Effect of vermin composts produced from cattle manure, food waste and paper waste on the growth and yield of peppers in the field. Pedobiologia.49: 297- 306.

Bjorneberg, D.L., Santos, F.L., Castanheira, N.S., Martins, O.C., Reis, J.L., Aase, J.K. and Sojka, R.E. 2003. Using polyacrylamide with sprinkler irrigation to improve infiltration. J. Soil Water Conserv., 58: 283-289.

Costa, L.D. and Gianquinto, G. 2002. Water stress and water table depth influence yield, water use efficiency, and nitrogen recovery in bell pepper: lysimeter studies. Aust. J. Agric. Res. 53(2): 201-210.

Curtis, M.J. and Claassen, V.P. 2005. Compost incorporation increases plant available water in a drastically disturbed serpentine soil. Soil Sci., 170: 939-953.

Doorenbos, J. and Kassam, A.H. 1986. Yield response to water. Irrigation and Drainage Paper, FAO, Rome, Italy, No. 33, p. 112.
El-Hadi, O.A. and Camelia, Y.E. 2004. "The conditioning effect of composts (natural) or/ and acrylamide hydrogels (synthesized) on a sandy calcareous soil. Growth response, nutrients uptake and water and fertilizers us efficiency by tomato plants”. J. App. Sci. Res.2 (12): 12931297.

Flanagan, D.C., Norton, L.D., Peterson, J.R. and Chaudhari, K. 2003. Using polyacrylamide to control erosion on agricultural and disturbed soils in rainfed areas: advances in the use of polyacrylamide (PAM) for soil and water management. J. Soil Water Conserv 58: 301-311.

Jaimez, R.E., Vielma, O., Rada, F. and GarciaNunez, C. 2000. Effects of Water Deficit on the Dynamics of Flowering and Fruit Production in Capsicum. Chinese Jacque in a tropical semiarid region of Venezuela. J. Agron. Crop Sci., 185: 113-119.

Khan, M.A.I., Farooque, A.M., Hrahim, M.A. and Haque, A. 2009. Effect of irrigation levels at growth stages on growth parameters and yield of four selected chili. Bangladesh J. Agric. Res. 34(1): 143-155.

Lakhdar, A., Rabhi, M., Ghnaya, T., Montemurro, F., Jedidi, N. and Abdelly, C. 2009. Effectiveness of compost use in salt-affected soil. J. Hazardous Materials. 171: 29-37.

Lentz, R.D. and Sojka, R.E. 2009. Long-term polyacrylamide formulation effects on soil erosion, water infiltration, and yields of furrow-irrigated crops. Agron J. 101: 305-314.

Liu, M.C. and Chen, D.K. 2002. Effects of deficit irrigation on yield and quality of cherry tomato (Lycopersicon esculentum var. cerasiforme Alef.). China Vegetables 6: 4-6.

Mahajan. G. and Singh, K.G. 2006. Response of greenhouse tomato to irrigation and fertigation. Agriculture. Water Management. 84(1-2): 202206.

Mitchell, J.P., Shennan, C. and Grattan, S.R. 1991. Developmental changes in tomato fruit composition in response to water deficit and salinity. Plant Physiol. 83: 177-185.

Ngouajio, M., Wang, G. and Goldy, R.G. 2008. Timing of irrigation initiation affects IWUE and yield of bell pepper under plastic mulch. J. Ame. Soc. Hort. Sci. 18: 325-344.

Nguyen,T.T., Fuentes, S. and Marschner, P. 2012. Effects of compost on water availability and gas exchange in tomato during drought and recovery. Plant Soil Environ., 58(11): 495-502. 
Okesusi, W.T. and Olorunwa, F. 2006. Experimental determination of growth and yield response of bell pepper to irrigation with diary waste water. Nig. J. Tech. Dev., 6(3): 56-65.

Poresmaiil, P., Habibi, D. and Roshan, B. 2007. Super absorbent polymer a way for reducing agricultural water use. Agric. and Natural Resources Engineering Disciplinary Organization, Vol. 15, pp. 80-82.

Ranganna, C. 1979. Manual of analysis of fruit vegetable products. Tatame. Graw Hill Publishing Company Limited New Delhi $\left(2^{\text {nd }} e d\right)$. pp. 105-119.

Sayyari, M. and Ghanbari, F. 2012. Effects of Super Absorbent Polymer A200 on the Growth Yield and Some Physiological Responses in Sweet Pepper (Capsicum Annuum L.) Under Various Irrigation Regimes. International. J. Agric. and Food Res., 1(1): 1-11.

Sezen,S.M., Yazar, A., Tekin, S., Eker, S. and Kapur, B. 2011. Yield and quality response of drip-irrigated pepper under Mediterranean climatic conditions to various water regimes. African. J. Biotechnology, 10(8): 1329-1339.

Snedercor, G.W. and Cochran, W.G. 1980. Statistial Methoods, $7^{\text {th }}$ Ed., The lowa State Univ., Press, Ames., lowa, U.S.A. pp. 83-94.

Tejada, M., Hernandez, M.T. and Garcia, C. 2009. Soil restoration using composted plant residues: Effects on soil properties. Soil and Tillage Research. 102: 109-117.

Yazdani, F., Aladadi, I., Akbari, G. and Behbehani, M.R. 2007. Effect of different rates of super absorbent polymer (Tarawat A200) on soybean (Glycine max L.) yield and yield components", Pajouhesh and Sazandegi. 75: 167177.

Wallace, D.H. and Munger, H.M. 1965. Studies of the physiological basis for yield differences.1. growth and analysis of six dry bean varieties. Crop Sci., 5: 343-348. 